\title{
Jurnalisme Multikultural: Gagasan Mengembangkan Cara Pendekatan Pengkajiannya
}

\author{
Amirudin \\ Program Studi Atropologi Sosial, Fakultas Ilmu Budaya \\ Universitas Diponegoro Semarang \\ Email: amdjtg@yahoo.com
}

\begin{abstract}
THIS- article is meant to provoke how the discourse of multiculturalism as a cultural conception can be realized in journalism practice on TV stations. This idea is important to conclude how multiculturalism can be represented in newscast products in which produced by media actors. Through the concept of field (Bourdieu 1993, 2005), which explains how this ideas can be practiced into some models of multicultural journalism that can create some cultural products in the form of multicultural news on TV stations. The method used is certainly the ethnography to reveal how the practice of multicultural journalism among media people at TV stations is already on the certain level, by conducting interviews and close observation on every movement of news actors especially for religious, cultural, and political issues.
\end{abstract}

Keywords: Multiculturalism, Multicultural Journalism, Fields, and TV Stations.

\section{Pendahuluan}

Secara sosiologis, masyarakat kita adalah multikultural. Selain warga masyarakat kita menjadi bagian dari warga masyarakat budaya - yakni himpunan warga yang tergabung dalam kelompok budaya menurut suku, agama, ras, antargolongan, dan gender (SARAG); warga masyarakat kita sekaligus juga menjadi bagian dari warga masyarakat politik - yakni himpunan warga yang mengikatkan diri dalam satuan politik berupa desa/kota, kabupaten, provinsi, dan NKRI, untuk bersama-sama bercita-cita mendapatkan kesejahteraan dan kemakmuran.

Dalam konteks itu, media punya peran besar memediasi bagaimana kehidupan masyarakat politik kita yang multikultural dari sisi kelompok budaya, bisa hidup berdampingan, damai dalam menjalani kehidupan dengan berpedoman pada prinsipprinsip multikultiralisme. Hanya saja dalam prakteknnya tidak sedikit media yang justru memposisikan dirinya bukan sebagai wahana untuk memediasi, tetapi justru memprovokasi situasi. Potensi kognisi tradisional dari warga yang cenderung oposisi biner dalam berlogika dan berpikir, seperti skema pribumi non-pribumi, Islam non Islam, kaya dan miskin, serta laki perempuan, seringkali terkuatkan sekat-sekat itu oleh media melalui produk-produk berita yang dihasilkan dariaktivitas jurnalismenya.

Data berikut ini, yang menggambarkan bagaimana peristiwa Kekerasan Kelompok Beragama $(\mathrm{KKB})$ dan tindak pelanggarannya yang terus meningkat, menandakan bahwa praktek multikultralisme belum jalan, dan jurnalisme media justru berperan makin mengentalkan sekat-sekat mereka. 


\section{Diagram-1}

Data Peristiwa Kemerdekaan Beragama atau Berkeyakinan (KKB) dan Tindak Pelanggarannya

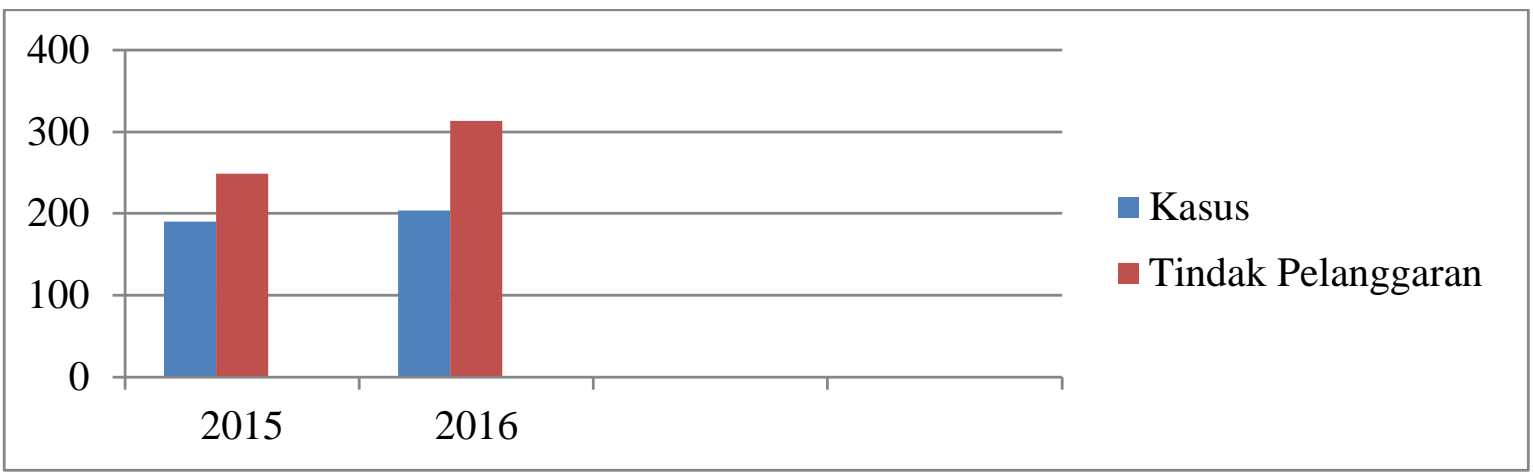

\section{Sumber:}

Data Peluncuran Laporan KKB Wahid Foundation, 2016

Berdasarkan laporan pelaksanaan kajian Kemerdekaan Beragama atau Berkeyakinan (KKB) Wahid Foundation pada 2016 sebagaimana tergambar dalam diagram-1 menunjukkan, kemerdekaan beragama atau berkeyakinan kita masih menghadapi masalah. Jumlah peristiwa KKB di 2015 ada 190 dengan 249 tindakan pelanggaran, dan 2016 ada 204 peristiwa dengan 313 tindakan pelanggaran. Angka tindak pelanggarannya naik sebesar $7 \%$. Begitupun terhadap jumlah aduan dugaan pelanggaran KKB juga meningkat. Di tahui 2015sebanyak 74 kasus, 2016 seebsar 89 kasus [Komnas HAM, 2016].

Banyak riset yang dilakukan yang mengkaitkan media dan budaya untuk menjawab persoalan itu seperti riset yang dilakukan Anton Novenanto (2009) tentang Mediated Dissater" the Role of Alternative and Mainstream Media in the East Java Mud Vulcano Disaster, dan Fitri (2011) tentang Analisis Wacana Khilafah dalam Perspektif KebijakanKebijakan Publik Pemerintah (Studi pada Bulletin Dakwah al Islam Edisi 04/XVII). Begitupun riset-riset yang secara spesifik mengangkat gagasan multikulturalisme bagaimana disemai di negeri ini seperti yang dilakukan Sumanto Al Qurtuby misalnya telah meneliti arus Cina - Islam - Jawa yang menunjukkan proses akulturasi di ketiga entitas sosial budaya itu telah terjadi. Menurutnya, Komunitas Cina telah menunjukkan andil besar dalam proses historisasi islamisasi di Jawa pada Abad ke-15 dan ke-16 yang berasal dari Kanton, Chuang-Chou, Chang-Chou, Yunan, Swatow dan kawasan lain di Cina Selatan yang memang sejak awal merupakan basis Islam. Mereka datang ke Jawa dan kawasan lain di Asia Tenggara sebagai pedagang, turis, zending profesional, maupun pelarian politik (2003: 231).

Lain daripada itu, penelitian Chang-Yau Hoon yang meneliti "Ras, Kelas, dan Stereotipikasi dalam Persepsi Pribumi tentang Ketionghoaan". Penelitiannya memiliki keunggulan karena kajiannya mampu mengungkap interaksi pribumi - non pribumi yang menunjukkan relevansi "ras", "kelas", "agama", dan "pendidikan" dalam menegaskan perbedaan etnis dan mengedepankan sekat-sekat etnis. Tanda-tanda yang berakar pada sekat itu masih berjalan sedemikian rupa hingga tanda-tanda itu membatasi hibriditas (Hoon, 2012: 251). 
Keempat studi itu, menurut peneliti, mengandung kelemahan: Pertama, studi Anton Novenanto (2009), Fitri (2011) yang memposisikan media justru sebagai kepanjangan kepentingan kelompok kekuatan ekonomi politik dan/atau kelompok agama dominan yang turut mem-frame media menguatkan dominasi mereka. Begitupun studi Al Qurtubi (2003), dan Hoon (2012) yang lebih banyak melihat proses akulturasi Cina - Jawa - Islam hanya dari sudut pandang sejarah sosial keagamaan dan tidak melihat bagaimana konstruksi akulturasi Cina - Islam - Jawa terwujud dalam kehidupan sehari-hari di ruang-ruang sosial suatu masyarakat. Juga studi Hoon (2012) yang hanya fokus pada cara pandang esensialisme dalam studi kebudayaan. Studinya hanya lekat pada bagaimana praktik kehidupan sehari-hari dalam relasi Jawa - Cina diarahkan oleh penegasan pembeda tanda-tanda ras dan sterotip dalam kehidupan sehari-hari. Jika demikian maka studi ini hanya menguatkan identitas suatu etnik menjadi sesuatu yang "taken for granted", diturunkan secara turun-temurun, tanpa ada peluang bagi mereka melahirkan carapandang kebudayaan baru dalam suatu proses relasi pribumi nonpribumi yang heterogin di sektor apapun.

Bertolak dari pemikiran Bourdieu (1997) mengenai "praktik" dalam suatu "field", penulis merasa perlu mulai dikembakan kajian yang mengungkap bagaimana orangorang media menggunakan jurnalisme untuk mengkomunikasikan multikulturalisme di ruang publik. Dengan mengambil lokus kajian di media televisi, bagaimana praktek multikulturalisme itu diproduksi dan direproduksi melalui aktivitas jurnalisme oleh orang-orang media hingga terwujud dalam produk-produk kebudayaan berupa berita agama, budaya, dan politik, rasanya sudah mulai perlu untuk dikembangkan. Melalui kajian semacam ini, penulis meyakini akan ditemukan model-model praktek multikulturalisme yang terwujud di ranah jurnalisme.

\section{Konsep Field sebagai Jalan Menuju Kajian Jurnalisme Multikultural}

Umumnya kajian tentang bagaimana multikulturalisme sebagai suatu konsepsi kebudayaan bisa diwujudan dalam praktek jurnalisme yang menjadi sebab angka KKB meningkat, didekati dengan penggunakan konsep ranah (field) yang dikenalkan Bourdieu $(1993,2005)$. Konsep ranah dalam hal ini mengacu pada Bourdieu yang mendefinsikan ranah sebagai "sistem hubungan" yang di dalamnya melibatkan aktor-aktor yang saling berinteraksi secara dinamis hingga melahirkan produk-produk kebudayaan berbentuk kebudayaan nonmateri (sistem ide, gagasan, nilai-nilai, sistem simbolik) maupun kebudayaan materi di institusi pendidikan. Dinamika relasi antar aktor yang berlangsung akan ditelusuri dan diikuti hingga melahirkan produk kebudayaan multikukultural, yang kemudian dieksplisitasi ke dalam model jurnalisme yang dapat diterapkan di mediamedia lainnya.

Kajian dengan kobnsep field ini perlu dilakukan untuk mengisi kekosongan studi, dari studi-studi yang sudah ada tentang jurnalisme di mana sejumlah studi yang ada umumnya bersifat esensialis yang menempatkan kelompok budaya sebagai faktor pembeda yang direalisasikan dalam aktivitas jurnalisme. Studi-studi semacam ini justru makin menegaskan pendefinisian identitas: ada kategori kelompok budaya yang dominan dan tidak dominan dalam praktik bermedia.

Apa yang dimaksud dengan kelompok budaya. Isitilah "kelompok budaya" secara umum sebenarnya telah banyak digunakan untuk mengakategorisasikan manusia atas dasar ciri-ciri biologis yang dianggap bersifat turun-temurun. Kelompok budaya 
merupakan penampilan fisik lahiriah yang berbeda (Worchel dalam Hoon, 2012), dan secara historis ketegori kelompok budaya ini dulu digunakan untuk membedakan tingkat kecerdasan, perilaku dan moralitas kelompok-kelompok budaya yang berbeda. Akan tetapi belakangan para ilmuan sosial tidak lagi menggunakan istilah ini sebagai cara untuk mengkategorisasikan kelompok-kelompok manusia karena kesahihan ilmiahnya lemah. Meskipun demikian, ras masih memiliki daya pikat sebagai sebuah kategori sosial (Hoon, 2012). Di Indonesia, orang Tionghoa umumnya dikenali oleh kaum pribumi maupun sesama Tionghoa dari ciri lahiriyah yang "berbeda", misalnya dari warna kulitnya yang lebih terang, bermata sipit, berambut lurus, dan bertulang pipi menonjol dibanding dengan kaum pribumi (Gondomono dalam Hoon, 2012). Penampilan fisik ini sering menjadi dasar stereotip.

Artikel Luke dan Carrington, "Race-Matters", menjelaskan "ras" sebagai penanda politik identitas, yang merupakan "prinsip dasar organisasi sosial dan pembentukan identitas yang menggerakkan orang bertindak dengan cara-cara tertentu (Hoon, 2012). Penanda ras benar-benar mempengaruhi cara orang dalam memandang, berinteraksi dengan dan mengkonstruksikan "si liyan yang dirasialisasikan". Anthias dan YuvalDavis berpednapat bahwa "ras" bisa merupakan satu cara bagaimana sekat dibangun di antara mereka yang dapat dan tidak dapat menjadi bagian dari konstruksi khusus suatu entitas kolektif penduduk" (Hoon, 2012). Sekat atau batas ini sering didefinisikan dan atas dasar inilah kelompok-kelompok manusia secara sosial diklasifikasikan. Orang cenderung melakukan estimasi homogenitas intra-kategori maupun perbedaan antarkategori secara berlebihan. Penilaian yang berlebihan ini berakibat pada reifikasi kelompok-kelompok.

Stuart Hall menganggap stereotipikasi merupakan suatu praktik penandaan yang sangat penting buat mempresentasikan perbedaan "rasial" (1987: 257). Ia menyatakan stereotip mewujud dalam bentuk beberapa ciri tentang seseorang yang umum dikenali dan mudah dipahami, mudah diingat, gambalng serta sederhana, yang meredusir segala hal tentang orang itu kedalam sifat-sifat tersebut, melebih-lebihkan dan menyederhanakannya, dan membakukannya tanpa perubahan atau perkembangan ke dalam keabadian. Singkatnya, stereotipikasi meredusir, meng-esensialisasikan, mengalamiahkan dan menetapkan perbedaan-perbedaan.

Meskipun demikian, manusia umumnya tidak dapat menghindar dari menciptakan stereotip, karena manusia tidak dapat bergerak tanpa stereotip. Stereotip berfungsi sebagai bagian dari pemeliharaan tatanan sosial dan simbolik. Stereotip mengekalkan suatu perasaan berbeda antara "Diri" dan "Liyan", dan menciptakan sekat imajiner antara "yang normal" dan "tidak normal", "yang bisa diterima" dan "tidak bisa diterima", serta "kita" dan "mereka". Gilman (1985:18) mencatat bahwa garis imajiner sendiri, begitu pula hubungan antara "Diri" dan "Liyan" yang bisa berubah. Dengan demikian sang "kita" yang dianggap "normal" secara artifisial bisa dibayangkan sebagai sebuah komunitas atau kolektivitas yang bersatu dengan suara gabungan. Di pihak lain, "mereka" diredusir menjadi si "liyan" yang di-esensialisasikan homogen, yang perbedaannya dengan kuat dipelihara melalui stereotip yang memisahkan "mereka" dari "kita". Pereduksian si "liyan" Tionghoa dari si "Diri" Pribumi telah memperkeras sekat rasial antara kedua kolektivitas ras yang "berbeda itu". 


\section{Kriitik terhadap Kajian-Kajian Multikulturalisme}

Dalam dunia riset, banyak riset yang telah dilakukan dimaksudkan untuk mengembangkan multikultulturalisme dari sisi ras, tetapi yang terjadi justru hasil riset makin memperkeras sekat-sekat rasialisme di antara kedua kelompok ras yang berbeda. Sejumlah riset itu, antara lain.

Pertama, penelitian Al Qurtubi (2003) yang meneliti Arus Cina-Islam-Jawa dengan pendekatan sejarah yang menemukan bahwa komunitas Cina tidak terbantahkan memiliki andil besar dalam proses islamisasi di Jawa pada abad ke-15 dan ke-16. Komunitas Cina yang memainkan peran signifikan dalam historisitas islamisasi di Jawa ini awalnya kebanyaka berasal dari Kanton, Chuang-chou, Chang-Chou (sekitar Amoy), Yunan, Swatow dan kawasan lain di Cina Selatan yang memang sejak semula dikenal sebagai basis-basis Islam di sana. Mereka datang ke Jawa dan kawasan lain di Asia Tenggara sebagai pedagang, turis, zending, profesional maupun pelarian politik. Komunitas "Cina Rantau" kemudian membaur dengan masyarakat setempat maupun masyarakat asing yang datang ke Jawa untuk keperluan dan motivasi yang sama. Mereka juga melakukan perkawinan dengan perempuan lokal sehingga membentuk apa yang disebut Sino-Javanese subculture.

Warga Cina yang semula merupakan komunitas sporadis di kemudian hari menjadi masyarakat yang terstruktur rapi dan mampu tampil sebagai kelas menengah yang bergengsi dan berwibawa berkat kesuksesan mereka di perdangan internasional. Kemakmuran material menjadikan mereka tampil sebagai kelas sosial yang mandiri, otonom, dan independen, bebas dari ketergantungan terhadap pemerintahan lokal Jawa yang berbasis di pedalaman. Pada saat yang bersamaan, kemajuan di bidang perniagaan ini mampu menarik masyarakat Jawa di pedalaman untuk ikut ambil bagian dalam proses niaga. Maka pada saat itu terjadi arus urbanisasi dalam skala besar yang menyebabkan pesisir Jawa menjadi pusat pertumbuhan demografi.

Kemajuan dan kemakmuran kota-kota pesisir ini hampir-hampir meruntuhkan mitos-mitos tradisional yang selama ini dipegang kuat bangsawan keraton; mitos darah biru; mitos perkawinan antarbangsawan, mitos pejabat keraton yang sakral dan lain-lain nyaris pudar, tenggelam oleh hiruk-pikuk kosmopolitanisme dan keramaian niaga di pesisir Jawa. Dengan kata lain, internasionalisasi berdampak pada independensi sekaligus kemandirian sikap pada pribadi masyarakat Jawa. Kemakmuran material yang mereka capai juga menimbulkan dampak yang tak terelakkan, yakni semakin menipisnya tingkat loyalitas masyarakat terhadap pemerintahan lokal Majapahit. Lebih jauh, keuntungan atau laba hasil perdagangan internasional ini kemudian digunakan untuk membangun jaringan politik guna merontokan kekuasaan agraris majapahit di pedalaman yang berbasis Hinduisme. Sejarahpun mencatat, kekuasaan Majapahit yang menjulang itu tumbang oleh sebuah kekuatan baru yang bernama Islam.

Meskipun pendatang baru, Islam memiliki daya pesona tersendiri buat masyarakat Jawa. Watak ajarannya yang egaliter dan tidak mengenal sistem kasta, proses ritualnya yang sederhana, praktis tidak membutuhkan banyak syarat dan tidak berbelitbelit (njlimet) merupakan daya pesona tersendiri buat masyarakat luar yang ingin berkenalan dengan Islam. Belum lagi metode "tasawuf kota" (urban sufism) yang dikembangkan para zending. Muslim yang sedikit banyak kompatibel dengan watak spiritualisme lokal Jawa semakin menambah gairah masyarakat setempat untuk memeluk agama Islam. Karakteristik ajaran internal Islam yang universal, populis, 
egalister, praktis dan all-inclusive ini ditambah oleh fakta kemakmuran ekonomi kaum Muslim pendatang, sehingga semakin merangsang masyarakat setempat untuk beragama Islam. Proses konversi agama dari Hinduisme/Budhisme dan kepercayaan lokal lain ke agama Islam pada bentangan abad ke-15/16 ini berlangsung cukup masif dan serempak di sepanjang pesisir Jawa, sehingga tidak berlebihan jika dikatakan bahwa kurun itu telah terjadi revolusi keagamaan yang dalam waktu tidak begitu lama mampu menggantikan sistem agama lain (Hindhuisme, Budhisme, Jawaisme) yang sudah mapan di negeri ini. Sebelum agama ini kembali ke terperangkap ke alam mitis dan dunia klenik di zaman Mataram, Islam pernah menunjukkan diri sebagai kekuatan urban yang memukau. Dan agen yang bertindak sebagai "driving force" arus konversi da sekaligus pemrakarsa urbanisme dan kosmopolinasme Islam ini adalah Komunitas Cina Muslim.

Kritik terhadap studi ini, sekalipun ibarat seseorang yang hendak memotret sebuah objek, penelitian ini sudah berhasil mengungkapkan banyak lanskap, tetapi tidak semua lanskap ter-cover dalam suatu penelitian. Dan riset ini mengesankan masih ada kesan mengunggulkan dominasi ras Cina dalam proses Islamisasi di Jawa.

Kedua, penelitian Hoon (2012) tentang "Ras, kelas, dan Stereotipikiasi: Persepsi Pribumi tentang Ketionghoaan". Studi ini mengkaji relevansi dan perlunya analisis persepsi mengenai "ras" dalam kajian tentang hubungan Pribumi dan Tionghoa dalam masyarakat Indonesia mutakhir. Meskipun "ras" tidak populer dalam wacana akademik mengenai etnisitas dan kajian multikultural, dalam wacana publik di Jakarta, hal ini sungguh merupakan sesuatu yang mendasar dan mengakar. Studi ini telah menunjukkan bahwa penanda-penanda ras tertentu mempengaruhi cara orang mempersepsikan, mengkonstruksikan dan berinteraksi dengan si-“liyan" yang direalisasikan. Dalam proses bagaimana orang pribumi membangun stereotip tentang orang Tionghoa, kolektivitas Pribumi dibayangkan sebagai sebuah kategori ras yang homogen yang dipersandingkan dengan si-“Liyan" Tionghioa. Sekat perbedaan antara Pribumi dan Tionghoa dibayangkan dan dipelihara melalui pengekalan stereotip dan mitos mengenai ciri-ciri suatu kelompok ras. Tidak satupun dari stereotip ini bebas dari konteks sejarahnya.

Dalam kajian ini jelas bahwa orang Tionghoa dikonstruksikan sebagai bos yang berkuasa dan kaya, yang diperhadapkan dengan Pribumi sebagai korban tak berdaya dan miskin. Konstruksi ini membakukan orang Tionghoa sebagain pelaku penindasan, sedangkan Pribumi sebagai korban tak berdaya. Reduksionisme yang simplistik seperti ini mengabaikan dinamika hubungan kekuasaan yang kompleks antara negara, pribumi dan Tionghoa. Akibanya keragaman di dalam kategori "Diri" atas dasar kelas, gender, etnisitas, budaya dan agama, diabaikan, dan kategori "Diri" da "Liyan" dilebih-lebihkan dalam dualisme yang tak dapat direkonsialisasikan sedemikian rupa sehingga "garis imajiner" perbedaan yang diesensialisasikan itu dapat dipertahankan.

Kajian ini juga mengungkap beberapa narasi tandingan terhadap stereotip yang lazim mengenai orang Tionghoa. Kendati narasi tandingan itu memiliki makna positif tentang bagaimana stereotip yang didasarkan atas mitos dan generalisasi itu bisa dibalikan, narasi tandingan itu tokh tidak mampu membuyarkan atau mematahkan sekat perbedaan ras. Ini berarti membalik stereotip mungkin bukan merupakan cara yang paling efektif untuk menandingi stereotip.

Kitik terhadap studi ini sama, kajian ini terlalu fokus pada penegasan pembeda yang bermula pada persepsi tentang identitas sebagai sebuah entitas tungal yakni dalam pengertian yang esensialis. Etnis Tionghoa dalam perspesi pribumi akan terus dipandang 
sebagai "pendatang" dan "orang numpang" selama reifikasi ras atas dasar esensialisme tetap merupakan wacana yang dominan dalam masyarakat Indonesia.

Ketiga, penelitian Hoon (2012) tentang “Menjaga Etnisitas: Menegosiasikan Pemeliharan Sekat dan Penyebarangan Batas" yang mengkaji proses pendefinisian dan pemeliharaan sekat etnis antara Pribumi dan Tionghoa dari sudutpandang Orang Tionghoa sendiri. Kajian ini menemukan, interaksi orang Tionghoa dengan Pribumi dalam kehidupan sehari-hari menunjukkan relevansi ras, kelas, agama, dan pendidikan dalam menegaskan perbedaan etnis dan mengedepankan sekat-sekat etnis. Akan tetapi ditunjukkan bahwa unsur-unsur pokok perbedaan etnis dipandang secara berbeda oleh orang Tionghoa dari generasi yang berbeda. Walaupun generasi tua berperan penting dalam menanamkan stereotip ras di dalam diri generasi muda Tionghoa, perbedaan dalam mengalami diskriminasi, hubungan antar etnis mobilitas fisik dan lingkungan kerja serta pendidikan, membentuk persepsi yang berbeda antara generasi yang satu dan yang lainnya. Hasilnya, garis imajiner yang menentukan sekat etnis juga bergeser. Kendati sekat etnis dipelihara, melintasi sekat dan hibriditas juga bukan merupakan sesuatu yang aneh. Sayang sekali tanda-tanda yang berakar pada sekat tertentu masih berjalan sedemikian rupa sehingga tanda-tanda itu membatasi hibriditas.

Kitik terhadap studi ini sama, kajian ini terlalu fokus pada penegasan pembeda yang bermula pada persepsi tentang identitas sebagai sebuah entitas tungal yakni dalam pengertian yang esensialis. Orang pribumi dalam persepsi orang Tionghoa akan terus dipandang berbeda secara turun-temurun dari generasi ke generasi selama reifikasi ras atas dasar esensialisme tetap menjadi wacana dominan dalam riset.

Keempat, penelitian Ahmad Atabik (2016: 7-17) mengenai “Pencampuran Budaya Jawa dan Cina: Harmoni dan Toleransi Beragama Masyarakat Lasem". Kajian ini mengungkap realitas nilai-nilai harmoni dan toleransi dalam proses asimilisasi etnik Tionghoa dan Orang Jawa di Lasem. Studinya menemukan, sejarah interaksi sosial yang terjadi antara orang Lasem dengan Etnis Cina berlangsung sejak abad ke-14 hingga ke-16. Meskipun interaksi kedua etnis ini mengalami pasang surut, namun harmoni dan toleransi itu senantiasa berjalan baik.

Kedatangan etnis Cina di Lasem melahirkan kebudayaan dan pluralitas dalam masyarakat. Pluralitas itu membentuk sebuah harmonisasi kerukunan dalam beragama dan bersosial. Hubungan yang harmonis antara kedua etnis tersebut terutama ketika bersama-sama melawan penjajah Belanda di Bumi Lasem. Harmoni dan toleransi masyarakat muslim Lasem juga dapat dilihat dari interaksi penduduk asli secara baik dengan pendatang, baik yang beragama muslim maupun non muslim yang kebanyakan dari etnis Cina.

Dalam kehidupan sehari-hari, harmoni terjaga karena beberapa faktor, yakni perkawinan silang, perasaan bersaudara antarwarga, hinga terbukanya ruang-ruang sosial. Perkawinan silang antarwarga lintas etnik yang terdiri-dari orang Tionghoa, pribumi Jawa dan santri, terjadi sejak hadirnya orang Tionghoa di Lasem.

Kritik terhadap studi ini sekalipun telah memperlihatkan carapandang multikulturalisme kuat dalam mengungkap fakta, tetapi studi ini tidak masuk ke pengungkapan secara detail bagaimana suatu kebudayaan diproduksi oleh suatu kolektivitas yang melibatkan etnis Tionghoa dan Pribumi. Dan studi ini, seolah-olah membawa alam pikir bahwa toleransi dan harmoni itu menjadi seolah-olah ada - taken for granted - dan bersifat sui-genesis tanpa secara detail dikaji bagaimana itu dihasilkan. 
Berdasarkan pada sejumlah kelemahan studi yang ada, penelitian ini ingin mengembangkan bagaimana aktor-aktor jurnalisme di Kompas TV melakukan praktik membuat berita hingga melahirkan produk-produk kebudayaan berupa berita yang multikultural. Suatu penelitian kebudayaan yang keluar dari konsep kebudayaan yang bersifat esensialis yakni konsep kebudayaan yang diposisikan sebagai sistem konsepsi yang menjadikan dasar manusia melakukan interpretasi, atas dasar tafsiran-tafsiran mengenai suatu realitas menjadi acuan menggerakkan tindakan.

Riset ini tidak menempatkan konsep kebudayaan sebagai esensialis tetapi sebaliknya anti-esensialis, bagaimana manusia menciptakan kebudayaan sebagai suatu struktur-obyektif yang dikontruksi secara terus-menerus melalui praktek jurnalisme.

\section{Simpulan}

Bertolak dari keinginan mengkaji dan mengungkap dari dekat bagaimana praktik multikulturalisme diwujudkan dalam aktivitas jurnalisme yang melibatkan aktor-aktor media di Stasiun TV dalam memproduksi produk-produk kebudayaan berupa berita dengan bit agama, budaya, dan politik, dan mewujudkannya ke dalam model jurnalisme multikultural maka kajian perlu dilakukan dengan sejumlah tahapan sebagai berikut.

Pertama, kajian etnografi di mana peneliti nantinya melakukan fieldworks untuk mengenali praktik jurnalisme di stasiun TV dengan mengikuti pergerakan dan kegiatan para aktor (jurnalis, editor, dll) dalam menjalani proses jurnalisme yang telah berlangsung. Luaran dari tahapan ini adalah catatan etnografis yang mendeskripsikan aktivitas jurnalisme dalam menghasilkan produk-produk berita dalam isu agama, budaya, dan politik. Selain itu, di tahap ini juga peneliti akan berusaha menemukan dan menyimpulkan kebudayaan yang dihasilkan dari aktivitas jurnalisme para aktor dalam proses menghasilkan berita isu-isu yang multikultural. Luaran dari tahapan ini adalah Deskripsi Etnografis yang melukiskan bagaimana jurnalisme multikultural terbangun dari proses interaksi dinamis dari para aktor media. Selain itu, inti deskripsi etnografis juga akan dituliskan dalam bentuk artikel untuk publikasi ilmiah dalam rangka diseminasi dan perluasan gagasan di jurnal nasional terakreditasi.

Kedua, menemukan dan menyusun model jurnalisme multikultural yang mampu melahirkan produk-produk kebudayaan berupa berita yang multikultural. Luaran dari tahapan ini adalah model jurnalisme multikultural yang mampu melahirkan produkproduk kebudayaan berita berita multikultural.

Ketiga, menuliskan keseluruhan hasil kajia ke dalam bentuk etnografi yang mendeskripiskan bagaimana orang-orang media (news-people) memproduksi kebudayaan dalam bentuk tayangan berita yang bervis multikultural.

\section{Daftar Pustaka}

Al Qurtubi, Sumanto. 2003. Arus Cina-Islam-Jawa: Bongkar Sejarah atas Peranan Tionghoa dalam Penyebaran Agama Islam di Nusantara Abad XV \& XVI. Jakarta: LP3S dan Yayasan Nabil

Amirudin. 2018. Mengkongkritkan Multikulturalisme: Belajar dari Relasi Jawa - Cina di Lasem Rembang. Dalam "60 Tahun Antropologi Indonesia: Refleksi Kontribusi 
Antropologi untuk Indonesia." Jakarta: Pusat Kajian Antropologi, Departemen Antropologi FISIP UI. Prosiding (ISBN-978-602-51002-1-5), p 419.

Amirudin. 2018. Antropologi Media: Agama dan Produksi Budaya di Layar Kaca. Semarang: Undip Press (ISBN-978-979-097-488-3

Amirudin. 2017. Film Tanda Tanya: Suatu Gagasan Merealisasikan Multikulturalisme. Nusa: Jurnal Ilmu Bahasa dan Sastra. Semarang: e-ISSN 0216-535X Vol. 12, No. 4. http://ejournal.undip.ac.id/index.php/nusa/article/view.

Amirudin. 2004. Konflik Jurnalisme dan Penyelesaiannya: Pendekastan Kebudayaan. Jurnal Humaniora. Semarang: Lemlit Undip.

Atabik, Ahmad. 2016. Percampuran Budaya Jawa dan Cina: Harmoni dan Toleransin Bersama Masyarakat Lasem. Jurnal Kajian Kebudayaan Sabda. Semarang: ISSN 1410-7910 Vol. 1 Tahun 2016, p 1 7-18.

Bourdieu, Pierre. 1977. The Outline of a Theory of Practice, trans. R. Nice. Cambridge M.A.: Cambridge University Press.

Bourdieu, Pierre. 1992. Language and Symbolic Power. Cambridge: Polity Press.

Bourdieu, Pierre. 1993. The Field of Cultural Production: Eassys on Art and Literature. New York: Columbia University Press.

Bourdieu, Pierre. 1998. Practical on the Theory Reason of Action. California, Stanford: Stanford University Press.

Bourdieu, Pierre. 2005. Distinction: a Social Critique of a Judgement of Taste. trans. R. Nice. Cambridge, M.A.: Cambridge University Press.

Bourdieu, Pierre. 2010. Arena Produksi Kultural: Sebuah Kajian Sosiologi Budaya. Terjemahan Yudi Santosa. Yogyakarta: KreasiWacana.

Fitri. 2011. Analisis Wacana Khilafah dalam Perspektif Kebijakan-Kebijakan Publik Pemerintah (Studi pada Bulletin Dakwah al Islam Edisi 04/XVII). Other thesis. Malang: Malang: University of Muhammadiyah Malang

Hall, Stuart. 1987. "Politic of Identity", dalam terence Ranger, Yunas Samad dan Ossie Stuart (eds), Culture, Identity, danPolitics: Ethnic Minorituies in Britain. Aldershot, Avebury, p. 129-135

Hoon, Chang-Yay. 2012. Identitas Tionghoa Pasca Suharto: Budaya, Politik, dan Media. Jakarta: Inspeal Ahimsakarya Press 
Endogami: Jurnal Ilmiah Kajian Antropologi

E-ISSN : 2599-1078

Novenanto, Anton. 2009. Mediated Dissater"the Role of Alternative and Mainstream Media in the East Java Mud Vulcano Disaster. MA Thesis in Departement of Cultural Anthropology and Development Sociology. Leiden: University of Leaden.

Saputra, Teguh. 2014. Tarian Multikultural Sang Naga. Jakarta: Lembaga Studi Kapasitas Nasional 